\title{
Differential grazing by the mollusc Arion hortensis Fér. on cyanogenic and acyanogenic seedlings of the white clover, Trifolium repens $\mathrm{L}$.
}

\author{
J. C. Horrill* and \\ A. J. Richards
}

Department of Plant Biology, University of

Newcastle Upon Tyne NE1 7RU U.K.

The average amount of releasable cyanide in cyanogenic seedlings of white clover was found to increase by a third from age 5 days to age 35 days. Over this period levels of cyanide decrease in cotyledons, but increase in stems and young leaves.

The slug, Arion hortensis was introduced to mixed populations of mostly cyanogenic and mostly acyanogenic seedlings of white clover of known age for 12 hour periods, and grazing levels of known phenotype seedlings was scored according to whether damage to the seedlings was lethal or not. Slugs did not discriminate between seedling phenotypes with respect to grazing. No difference in the level of damage between phenotypes was detected at 5 days age. At 16,23 and 35 days age, very few grazed cyanogenic seedlings suffered lethal damage, although most grazed acyanogenic seedlings were lethally damaged. At these ages, most seedlings suffering non-lethal damage were cyanogenic.

It is concluded that older seedlings of cyanogenic white clover are protected from lethal grazing damage by the slug Arion hortensis. This may influence the frequency of cyanogenic morphs in populations more than discriminatory grazing on adult plants.

\section{INTRODUCTION}

It has been known for many years that certain morphs of the white clover, Trifolium repens $\mathrm{L}$. have the ability to release hydrogen cyanide from damaged leaves through the interaction of the cyanogenic glucosides linamarin and lotaustralin (locus Ac/ac) with the hydrolysing enzyme linamarase (locus $\mathrm{Li} / \mathrm{li}$ ). Individuals with the phenotype AcLi are cyanogenic, (Corkill, 1942; Atwood and Sullivan, 1943). A cline exists across Europe from the south-west to the north-east such that south-western populations are predominantly cyanogenic, and north-eastern populations predominantly acyanogenic (Daday, 1954; 1965). There is also a south-north cline for cyanogenesis in the birds-foot trefoil, Lotus corniculatus (Jones 1977), and in both species the unlinked Ac/ac and $\mathrm{Li} /$ li loci show a clinal variation similar to that of the cyanogenic/acyanogenic morphs.

Various authors have demonstrated that certain herbivores selectively graze acyanogenic morphs in both T. repens (e.g., Angseesing, 1974;

\footnotetext{
* Present address: Department of plant Biology and Ecology, University of St. Andrews, Fife, KY16 9TH, U.K.
}

Crawford-Sidebotham, 1972; Dritschilo et al., 1979 and Dirzo and Harper, 1982) and in L. corniculatus (e.g., Jones 1962; 1966; Compton et al., 1983). Such natural selection may account for the predominance of cyanogenic morphs in south-western regions. It is still not altogether clear why cyanogenic morphs become less common in the north-east, although Foulds and Grime (1972a, b) and Foulds and Young (1977) suggest that various types of edaphic and climatic stress favour acyanogenic morphs in both species, while similar effects have been noted in $T$. repens by Daday (1965), and Bishop and Korn (1969). Ennos (1981) shows that the Li allele is associated with fitness factors irrelevant to selective grazing in $T$. repens, including leaf size.

Most studies on selective grazing in $T$. repens and $L$. corniculatus concentrate on mature plants. It is difficult to work on seedlings because the testing for cyanogenesis involves the destructive harvesting of the seedling, so that inference of differential grazing can only be retrospective, and the design of experiments is problematic. However, both species are long-lived perennials with creeping vegetative reproduction forming large clones, and flowers are produced laterally. It is clear that 
once established, clones may tolerate substantial levels of grazing or its equivalent (for instance clover in a mown lawn or sileage crop). Certain levels of grazing may even stimulate a greater production of flowers and seed, by the removal of terminal buds, than occurs in the absence of grazing. It is likely that selective grazing of the acyanogenic morph at the seedling stage will influence morph ratios in adult populations more than grazing of established plants (CrawfordSidebotham, 1972).

The only report which investigates selective grazing on seedlings in either species is by Miller et al. (1975). In this study, seed of known cyanogenic phenotype (11 per cent cyanogenic) were sown in trays, and in the open ground, and exposed to grazing for about one month after germination. No differential survival of morphs from those expected in the seed population was observed in what the authors term a warm climate.

In the present study, seedling populations of $T$. repens which were an equal mixture of mostly cyanogenic, and mostly acyanogenic strains were exposed to grazing by the slug Arion hortensis (L.) at various ages in controlled conditions. Parallel experiments investigated the potential release of cyanide from various parts of cyanogenic seedlings at different ages.

\section{MATERIALS AND METHODS}

Seed of commercial varieties of $T$. repens $\mathrm{S} 100$ and S184 were obtained from M. A. Hughes with the information that the former strain tends to have mostly cyanogenic phenotypes, and the latter mostly acyanogenic phenotypes. Single batches only of each strain were used throughout. Duplicated sets of seed of each strain, each set with 80 seeds, were sown and grown as for grazing experiments (below), and each seedling was tested for cyanide production by the Guignard picrate test 23 days after germination. Duplicate sets did not differ significantly, and the mean percentage of cyanogenic seedlings from $\mathrm{S} 100$ proved to be 92 per cent and that from S184 was 8 per cent. It is assumed that samples of the seed from the same batches used for grazing experiments did not differ significantly from these proportions of cyanogenic morphs. However, Daday (1955) shows that proportions of cyanogenic morphs can differ widely between different batches of these strains. He records higher proportions of cyanogenic phenotypes amongst samples of $\mathrm{S} 184$ than we found.
Seeds were presoaked for 24 hours and sown on damp filter paper. After germination, seeds were transferred to trays containing Levington's peatbased compost and grown at 1 seedling $/ \mathrm{cm}^{2}$ at $20^{\circ} \mathrm{C}$ under artificial illumination with a 14 hour day and RH approximately 45 per cent. Germination of S184 proved faster and more reliable than S100.

Seedlings of similar ages were presented to slugs at ratios of $1: 1, \mathrm{~S} 100: \mathrm{S} 184$. Positioning of S100 (mostly cyanogenic) with respect to S184 (mostly acyanogenic) seedlings within an experiment was randomised by the use of a random number table when selecting planting sites. Each experiment was replicated within a tray up to four times by the use of aluminium dividers; replicate arrays displayed the same quasi-random arrangement of presumptive phenotypes.

Slugs of between 20 and $30 \mathrm{~mm}$ in length were gathered from the wild and kept on damp filter paper in petri dishes in the dark between experiments. Prior to each experiment slugs were starved (deprived of filter paper) for 48 hours. Six slugs were introduced into each seedling population of 80 or 130 seedlings for a 12 hour dark period at $15^{\circ} \mathrm{C}$, the experimental tray being covered by polythene film. At the end of each experiment all seedlings (which were of known strain) were scored for damage on the following subjective scale: 0 no damage, 1 indication of superficial grazing, 2 evidence of moderate grazing, further growth possible, 3 evidence of moderate grazing, no further growth possible, 4 extensive grazing, no further growth possible 5 , complete seedling consumed.

The amount of free cyanide released by maceration, by hand and with toluene, present in various tissues at various ages was quantified by Mitchell's (1974) modification of the Guignard picrate test. The Instrumentation Specialities Co. model SR spectroradiometer was used to measure reflectance of developed test papers at $603 \mathrm{~mm}$ maximum absorbtion. Calibration was obtained from 0 to $20 \mu \mathrm{gCN}^{-}$, using $2 \mathrm{M} \mathrm{KCN}$ and $2 \mathrm{M} \mathrm{HCl}$. Standardised samples of $0.05 \mathrm{~g}$ fresh weight of tissue were used throughout, and replicated once.

\section{RESULTS}

\section{Quantitative testing for cyanide}

Tests were restricted to $\mathrm{S} 100$ seedlings. Seedlings were compartmented into stem, cotyledons, first true leaf, and second and third true leaves (table 1). Mean values for $\mathrm{CN}^{-} / 0 \cdot 05 \mu \mathrm{g}$ fresh weight 
Table 1. Amount of cyanide released as detected by the Guignard picrate test from $0.05 \mathrm{~g}$ fresh weight samples from different tissues of cyanogenic seedlings of Trifolium repens $\mathrm{S} 100$ of known age. Cyanide as $\mu \mathrm{g} \mathrm{CN}^{-}$was assayed by calibration of reflectance spectrophotometer reading of test papers at $603 \mathrm{~nm}$ with known concentrations of cyanide

\begin{tabular}{|c|c|c|c|c|c|c|}
\hline \multirow{2}{*}{$\begin{array}{l}\begin{array}{l}\text { Age of seedling } \\
\text { (days) }\end{array} \\
\text { Tissue }\end{array}$} & \multicolumn{2}{|l|}{5} & \multicolumn{2}{|l|}{11} & \multicolumn{2}{|l|}{16} \\
\hline & stem & cotyledon & stem & cotyledon & stem & cotyledon \\
\hline $\mathrm{CN}^{-} /$tissue \pm S.E. & $5 \cdot 3 \pm 0.5$ & $12 \cdot 7 \pm 0 \cdot 3$ & $8 \cdot 7 \pm 0.4$ & $11 \cdot 5 \pm 0 \cdot 5$ & $10 \cdot 3 \pm 0 \cdot 02$ & $10 \cdot 7 \pm 0.4$ \\
\hline mean $\mathrm{CN}^{-} /$plant \pm S.E. & \multicolumn{2}{|c|}{$9 \cdot 0 \pm 0 \cdot 4$} & \multicolumn{2}{|c|}{$10 \cdot 1 \pm 0.45$} & \multicolumn{2}{|c|}{$10 \cdot 5 \pm 0 \cdot 3$} \\
\hline $\begin{array}{l}\text { Age of seedling } \\
\text { (days) }\end{array}$ & 23 & & & 35 & & \\
\hline Tissue & stem & cotyledon & first leaf & stem & first leaf & second leaf \\
\hline $\mathrm{CN}^{-} /$tissue \pm S.E. & $11 \cdot 6 \pm 0 \cdot 4$ & $9 \cdot 3 \pm 0 \cdot 7$ & $13 \cdot 1 \pm 0 \cdot 3$ & $11 \cdot 8 \pm 0 \cdot 5$ & $12 \cdot 5 \pm 0 \cdot 6$ & $12 \cdot 7 \pm 0 \cdot 4$ \\
\hline mean $\mathrm{CN}^{-} /$plant \pm S.E. & & $11 \cdot 3 \pm 0 \cdot 46$ & & & $12 \cdot 3 \pm 0 \cdot 5$ & \\
\hline
\end{tabular}

increased from $5 \cdot 3 \mu \mathrm{g}$ at 5 days to $11 \cdot 8 \mu \mathrm{g}$ at 35 days for stems. Conversely, values decreased from $12.7 \mu \mathrm{g}$ at 5 days to $9 \cdot 3 \mu \mathrm{g}$ at 23 days for cotyledons. Values for young true leaves varied little, ranging from 12.5 to $13 \cdot 1 \mu \mathrm{g} / 0.05 \mathrm{~g}$. The average amount of cyanide present $/ 0.05 \mathrm{~g}$ fresh weight increased steadily in seedlings from $9.0 \mu \mathrm{g}$ at 5 days to $12 \cdot 3 \mu \mathrm{g}$ at 35 days.

\section{Grazing experiments}

In the analysis of the grazing data, sample sizes of grazed seedlings were small, so scores relating to levels of grazing are bulked in such a way that scores 1 and 2 (seedling grazed, but capable of surviving) and scores 3,4 and 5 (seedling incapable of surviving because of grazing damage) are treated as two categories. It is considered that slugs detect the cyanide phenotype of a plant by grazing it (below). Therefore, comparisons are only made between grazed plants, and ungrazed plants are ignored in the analysis. Levels of grazing scored 1 and 2 are interpreted as plants which were sampled by the slugs and rejected. Levels of grazing scored 3,4 and 5 are interpreted as plants which were found to be palatable by the slugs.

The mean number of seedlings grazed by the slugs per experiment did not differ between the mostly cyanogenic and mostly acyanogenic seedlings. For S100 (most cyanogenic) this was $19 \cdot 85 \pm$ $2 \cdot 76$ and for $\mathrm{S} 184$ it was $22 \cdot 23 \pm 2 \cdot 35$. Therefore we assume that slugs cannot detect the cyanide phenotype of a plant before grazing it.

Statistical analysis was made of individual replicate experiments, and of replicated experiments bulked for age of seedling, by use of the $2 \times 2$ contingency chi-squared test (table 2). The null hypothesis tested was that the proportion of acyanogenic seedlings grazed against all seedlings grazed did not differ between damage scores 1 and 2 (seedling viable), and damage scores 3,4 , and 5 (seedlings inviable). In all cases where this hypothesis failed, more acyanogenic seedlings were rendered inviable by grazing than were cyanogenic seedlings. In seven out of nine of these cases, more cyanogenic seedllings survived grazing (scores 1 and 2) than did acyanogenic seedlings. In the other two cases, numbers did not differ.

The null hypothesis failed (i.e., more acyanogenic seedlings were killed and more cyanogenic seedlings survived grazing) in nine out of 13 experiments. In both experiments with fiveday-old seedlings, and in two out of three experiments with eleven-day-old seedlings the null hypothesis was upheld, that is equal proportions of cyanogenic and acyanogenic seedlings survived, or were killed, by grazing. In all other experiments, with seedlings aged 16 days, 23 days and 35 days, more acyanogenic seedlings were killed by grazing than were cyanogenic seedlings.

\section{DISCUSSION}

Our results suggest that the slug Arion hortensis is unable to differentiate between cyanogenic and acyanogenic seedlings of Trifolium repens until it grazes seedling tissue. After initial grazing, it does not discriminate between cyanogenic and acyanogenic five-day-old seedlings, and nearly all seedlings which are grazed subsequently die. Limited discrimination appears to occur with 
Table 2 Numbers of mostly cyanogenic seedlings $(C)$ and mostly acyanogenic seedlings (A) grazed by slugs in experiments in which equal numbers of cyanogenic and acyanogenic seedlings of known equal age and in random array were presented to slugs for $12 \mathrm{~h}$. Scores 1,2 seedling likely to survive grazing; scores 3,4 and 5 seedling killed by grazing.

\begin{tabular}{|c|c|c|c|c|c|}
\hline \multicolumn{2}{|c|}{$\begin{array}{l}\text { Age of seedling } \\
\text { in days from } \\
\text { germination }\end{array}$} & \multicolumn{3}{|c|}{ Grazing damage score } & $\begin{array}{l}\text { Significance } \\
\text { level }\end{array}$ \\
\hline \multirow[t]{6}{*}{5} & expt. 1 & $\mathrm{C}$ & 1 & 21 & \\
\hline & & A & 0 & 13 & n.s. \\
\hline & expt. 2 & $\mathrm{C}$ & 0 & 49 & \\
\hline & & A & 0 & 42 & n.s. \\
\hline & bulked & $\mathrm{C}$ & 1 & 70 & \\
\hline & & A & 0 & 55 & n.s. \\
\hline \multirow[t]{8}{*}{11} & expt. 1 & $\mathrm{C}$ & 5 & 9 & \\
\hline & & A & 3 & 7 & n.s. \\
\hline & expt. 2 & $\mathrm{C}$ & 8 & 18 & \\
\hline & & A & 2 & 20 & $*$ \\
\hline & expt. 3 & $\mathrm{C}$ & 3 & 15 & \\
\hline & & A & 6 & 25 & n.s. \\
\hline & bulked & $\mathrm{C}$ & 16 & 42 & \\
\hline & & A & 11 & 52 & $*$ \\
\hline \multirow[t]{8}{*}{16} & expt. 1 & $\mathrm{C}$ & 23 & 2 & \\
\hline & & A & 16 & 11 & $*$ \\
\hline & expt. 2 & $\mathrm{C}$ & 11 & 2 & \\
\hline & & A & 8 & 8 & $*$ \\
\hline & expt. 3 & $\mathrm{C}$ & 12 & 6 & \\
\hline & & A & 12 & 20 & $*$ \\
\hline & bulked & $\mathrm{C}$ & 46 & 10 & \\
\hline & & A & 36 & 39 & $*$ \\
\hline \multirow[t]{6}{*}{23} & expt. 1 & $\mathrm{C}$ & 10 & 0 & \\
\hline & & A & 8 & 9 & $*$ \\
\hline & expt. 2 & C & 18 & 0 & \\
\hline & & A & 5 & 17 & $*$ \\
\hline & bulked & $\mathrm{C}$ & 43 & 2 & \\
\hline & & A & 14 & 46 & $*$ \\
\hline \multirow[t]{6}{*}{35} & expt. 1 & $\mathrm{C}$ & 11 & 1 & $*$ \\
\hline & & A & 11 & 9 & \\
\hline & expt. 2 & C & 15 & 1 & $*$ \\
\hline & & A & 6 & 10 & \\
\hline & bulked & $\mathrm{C}$ & 26 & 2 & $*$ \\
\hline & & A & 17 & 19 & \\
\hline
\end{tabular}

n.s. not significant.

* Null hypothesis rejected at $p=0.001$.

respect to eleven-day-old seedlings, but marked discrimination occurs between cyanogenic and acyanogenic morphs of seedlings of 16,23 and 35 days. In older seedlings, very few cyanogenic seedlings are killed, but cyanogenic seedlings predominate in samples of seedlings that are grazed, but not killed. These results strongly suggest that cyanogenesis protects seedling $T$. repens of a certain age from fatal damage by $\boldsymbol{A}$. hortensis. Very young seedlings are not so protected, it appears, because total levels of cyanogenic glucosides are lower than in older plants, and are chiefly located in the cotyledons, leaving the vulnerable stem relatively unguarded.

These results contrast with those of Miller et al. (1975) who were unable to show differential survival of cyanogenic and acyanogenic seedlings in polymorphic populations. However, their populations were subjected to a wide range of potential selective forces, and even if selective grazing of cyanogenic morphs occurred (and this was not demonstrated), it may have been balanced by other selective constraints as discussed by Foulds and Grime (1972a,b), Foulds and Young (1977), Daday (1965), Bishop and Korn (1969), Ennos (1981) and others. In our experiments, we attempted to isolate the selective effect of one species of mollusc from all other selective constraints on the cyanogenic polymorphism. In doing so, we have shown that cyanogenic seedlings are relatively protected from death by that herbivore through at least part of their history. This is of interest, for as Crawford-Sidebotham (1972) has pointed out, the seedlings of $T$. repens are very vulnerable to lethal grazing by herbivores. Selective grazing of adult plants may have little effect on their survival and fitness, and natural selection by herbivores in favour of cyanogenic morphs in $T$. repens may mostly occur amongst seedlings.

Acknowledgement. We would like to thank M. A. Hughes for supply of seed and much useful advice about the culture of T. repens.

\section{REFERENCES}

ANGSEESING, J. P. A. 1974. Selective eating of the acyanogenic form of Trifolium repens. Heredity, 32, 73-83.

ATTWOOD, S. S. AND SUlLIVAN, J. T. 1943. Inheritance of a cyanogenetic glucoside and its hydrolysing enzyme in Trifolium repens. $J$. Heredity, 34, 311-320.

BISHOP, J. A., AND KORN, M. E. 1969. Natural selection and cyanogenesis in white clover, Trifolium repens. Heredity, $24,423-430$.

COMPTON, S. G., BEESLEY, S. G., AND JONES, D. A. 1983. On the polymorphism of cyanogenesis in Lotus corniculatus L. IX. Selective herbivory in natural populations at Porthdafarch, Anglesey. Heredity, 51, 537-547.

CORKILL, L. 1942. Cyanogenesis in white clover (Trifolium repens $\mathrm{L}$ ). V. The inheritance of cyanogenesis. N.Z. J. Sci. Techn., 23B, 178-193.

CRAWFORD-SIDEBOTHAM, T. J. 1972. The role of slugs and snails in the maintenance of the cyanogenesis polymorphisms of Lotus corniculatus and Trifolium repens. Heredity, $28,405-411$.

DADAY, H. 1954. Gene frequencies in wild populations of Trifolium repens 1 . Distribution by latitude. Heredity, 8 , 61-78.

DADAY, H. 1955. Cyanogenesis in strains of white clover (Trifolium repens L.) J. Brit. Grassland Soc., 10, 266-274. 
DADAY, H. 1965. Gene frequencies in wild populations of Trifolium repens $\mathrm{L}$. IV. Mechanism of natural selection. Heredity, 20, 355-366.

DRITSCHILO, W., KRUMMEL, J., NAFUS, D. AND PIMENTAL, D. 1979. Herbivorous insects colonising cyanogenic and acyanogenic Trifolium repens. Heredity, 42, 49-56.

DIRZO, R. AND HARPER, J. L. 1982. Experimental studies on slug-plant interactions III. Differences in the acceptability of individual plants of Trifolium repens to slugs and snails. J. Ecol., 70, 102-117.

ENNOS, R. A. 1981. Detection of selection in populations of white clover Trifolium repens L.). Biol. J. Linn. Soc., 15, 75-82.

FOULDS, W. AND GRIME, J. P. 1972a. The influence of soil moisture on the frequency of cyanogenic plants in populations of Trifolium repens and Lotus corniculatus. Heredity, 28, 143-146.

FOULDS, W. AND GRIME, J. P. 1972b. The response of cyanogenic and acyanogenic phenotypes of Trifolium repens to soil moisture supply. Heredity, 28, 181-187.
FOULDS, W. AND YOUNG, L. 1977. Effect of frosting, moisture stress and potassium cyanide on the metabolism of cyanogenic and acyanogenic phenotypes of Lotus corniculatus L. and Trifolium repens L. Heredity, 38, 19-24.

JONES, D. A. 1962. Selective eating of the acyanogenic form of the plant Lotus corniculatus L. by various animals. Nature, 193, 1109-1110.

JONES, D. A. 1966. On the polymorphism of cyanogenesis in Lotus corniculatus. Selection by animals. Can. J. Genet. Cytol., 8, 556-567.

JONES, D. A. 1977. On the polymorphism of cyanogenesis in Lotus corniculatus L. VII. The distribution of the cyanogenic form in western Europe. Heredity, 39, 27-44.

MILLER, J. D., GIBSON, P. B., COPE, W. A. AND KNIGHT, W. E. 1975. Herbivore feeding on cyanogenic and acyanogenic white clover seedlings. Crop Sci., 15, 90-91.

MITCHELL, N. D. 1974. Quantification of the picrate test for cyanide in plant genetic studies. Can. J. Genet. Cytol., 16, 895-897. 